\title{
BACTERIAL DIARRHOEA IN NEWLY BORN CALVES IN MENOUFIEA GOVERNORATE
}

\author{
ELHAM I. ATWA*, EMAN M. SHARAF ${ }^{*}$ and EMAN M. ZAKARY ${ }^{* *}$ \\ *Bacteriology Department Animal Health Research Institute of Egypt Shebin El- Kom branch. \\ ** Biotechnology Department, Animal Health Research Institute of Egypt.
}

\section{ABSTRACT}

Received at: 13/8/2012

Accepted: 24/11/2012
Out of 200 examined rectal swabs of diarrheic calves, 159 samples $79.5 \%$ were positive for bacteriological isolates. The recovered bacterial species were $E$. coli, $S$. typhimurum, Campylobacter sp, Corynebacyerium sp, $P$. aeruginosa and $C$. perfringens types $A$ and $B$ with incidence of $47.5,9,7.5,6,4$ and $5.5 \%$, respectively. Typing of $C$. perfringens by intradermal inoculation test in albino Guinea pig revealed that the incidence of toxigenic and non toxigenic strains were $(81.9 \%$ and $18.1 \%)$ respectively. $C$. perfringens type A was the most predominant to type B with the incidence of $45.5 \%$ and $36.4 \%$ respectively. The serological serotyping of $95 \mathrm{E}$. coli isolates revealed the following serotypes K99 $(21.1 \%)$, O157 (17.9\%), O111 (9.5\%), O125 (11.6\%), O119 (15.8\%), O26(12.6\%), O128 $(8.4 \%)$ and un typed E. coli (3.2\%). In vitro sensitivity of the recovered E.coli isolates to different antimicrobial agents shows that, E. coli isolates were highly sensitivite to enrofloxacin, flumequine and tetracycline. In contrast, these isolates were found to be resistant to ampicillin, erythromycin, gentamicin, lincomycin and penicillin-G. PCR panel could help diagnosticians rapidly determine the causative agents for bovine diarrhea in the early stages of disease and help practitioners initiate appropriate treatments or interventions quickly. Using PCR technique to improve the results, in case of $E$ coli $\mathrm{O} 157$ for $r f b$ gene the molecular bands appeared at $259 \mathrm{bp}$, E coli K 99 gene $F 41$ it appeared at $314 \mathrm{bp}$, while in Salmonella typhmiurium flic gene at $559 \mathrm{bp}$.

Keyword: Diarrhea, calves, E. coli, Salmonella C. perfringens

\section{INTRODUCTION}

Diarrhea is a major problem in livestock production in Egypt and throughout the world (Farid et al., 2001 and Ibrahim, 2007). Enteritis in newborn calves causes high morbidity and mortality, leading to significant economic losses in Egypt (Novert and Hammad, 2001 and Ashraf, 2007).

Diarrhea is a well-known clinical sign in neonatal animals. Its aetiology is complex involving management, environmental, nutritional, physiological variations and variety of pathogens including bacteria, viruses, protozoa and intestinal parasites are described as important agents causing diarrhea (either separately or in combination) in buffalo calves (Snodgrass et al., 1986; Roberts, 1993; El-Ghari et al., 1994 and

Prescott et al., 2008).

Enterotoxigenic E. coli (ETEC) and Salmonella are known to be the most common and economically important agents (SJ Achá et al., 2004) but other bacteria, e.g. Campylobacter spp. Clostridium sp, have also been identified as the cause of enteric disease and diarrhea in calves (Schoenians, 2006; Prescott et al., 2008 and Myers, 1984). The 2 latter groups also contain important human pathogens that may cause outbreaks of food-borne diseases (De Rycke et al., 1986) and thus are of high public health importance. In acute neonatal diarrhea, an important disease of calves, 4 micro-organisms in particular, are of widespread occurrence and proven enteropathogenicity: rotavirus, coronavirus, cryptosporidia and enterotoxigenic E. coli (Snodgrass, 1986).

Diarrhea due to $E$. coli is one of the most common diseases of young calves (Uhde, 2008), despite vaccination programs and management measures, necessitating treatment with antibiotics and fluid therapy (Gyles, 1993). E. coli diarrhea in newborn calves (9-10 days of age) is usually characterized by watery white or yellowish diarrhea, rapid onset and time course, and high mortality. In affected calves, diarrhea typically begins within 36-72 hours of birth, 
and affected calves die within 2-3 days. Some calves die several hours after appearing healthy and free of diarrhea. Calf scours is not a single disease entity; it is a clinical syndrome associated with several diseases characterized by diarrhea. Regardless of the cause, absorption of fluids from the intestine is altered, leading to life-threatening electrolyte imbalances. The scouring calf loses fluids, rapidly dehydrates, and suffers from electrolyte loss and acidosis. Infectious agents may cause initial damage to the intestine, but death from scours usually results from dehydration, acidosis, and loss of electrolytes. Identification of infectious agents that cause scours is essential for implementation of effective preventive and treatment measures (Radostits et al., 2007).

E. coli populations are divided into serotypes and serogroups on the basis of antigenic composition (somatic or $\mathrm{O}$ antigens, flagellar or $\mathrm{H}$ antigens, and capsular or K antigens; (Campos, 2004). In one study, the most common $E$. coli serotypes isolated from diarrheic fecal samples were O119, O111, O126, and O78 (Dean-Nystrom et al., 1997; Tamaki et al., 2005 and Badouei et al., 2010) isolated O157:H7, O111 and O26 serotypes of $E$. coli strains from 297 fecal samples, from 200 diarrheic and 97 non-diarrheic calves. The most predominant serogroup was O26 $(18.4 \%)$. Current treatment regimens for the treatment of neonatal calf diarrhea center on antimicrobial therapy and fluid therapy.

Salmonellosis is one of the major foodborne diseases. Due to its endemic nature, high morbidity and association with a wide range of foods, this zoonotic disease is of high public health concern (Aarestrup et al., 2007; Alizadeh et al., 2007 and Kottwitz et al., 2008).

Salmonella infections occur worldwide in both developed and developing countries and are a major contributor to morbidity and economic costs (Antoine et al., 2008).

Several rapid and sensitive methods have been developed for identification of Salmonella serovars from clinical samples (Zahraei et al., 2007). Especially $S$. typhimurium causes diarrhea in calves 2-12 wk old. Salmonella typhimurium is the most frequently isolated serovars from foodborne outbreaks throughout the world (Herikstad et al., 2002).

Salmonellae produce enterotoxins but are also invasive and produce inflammatory change within the intestine. In calves, infection commonly progresses to a bacteremia.

Targeting fliC gene specific for $S$. typhimurium. This gene is suitable for PCR targeted for detection of
Salmonella Serovars. (Malorny et al., 2003). Investigation of Salmonella infection in calves was the major strategy of our work in several localities, as well as to detect the most accurate sensitive and rapid diagnostic assay among different diagnostic procedures.

PCR is a useful diagnostic tool because it is quick, specific, sensitive, and relatively inexpensive. A PCR which detects genes (Stone et al., 1994 and China et al., 1996). The identification and differentiation of specific gene via PCR amplification of virulenceassociated genes commonly found in these E. coli strains. Primers specific for genes encoding the fimbrial subunits of $K 99, E$ coli $\mathrm{O} 157$ and S.typhimurium.

The aim of this work is the evaluation of the bacteriological aetiology of diarrhoea in newly born calves. Also, antimicrobial sensitivity of most isolated bacteria in diarrheic fecal samples to overcome the problem and reduce losses. On the other hand, using polymerase chain reaction (PCR) test to substitute the traditional methods and rapid diagnosis.

\section{MATERIALS and METHODS}

\section{Collection of samples:}

Rectal swabs were collected from (200) diarrheic calves using sterile cotton swabs, at different farms of Menoufiea, Gharbia and Qaliubiya Governorates in Egypt, to evaluate the performance of the PCR panel in comparison with other laboratory procedures routinely for the same target agents bacterial culture for $E$. coli K99, E coli O 157 bacterial culture and serotyping for Salmonella, and microscopic observation.

Samples were transferred directly to the laboratory in a separate clean sterile plastic bag, in an ice box and kept in retail package under complete aseptic condition without delay and subjected to required investigations.

\section{Bacteriological examination:}

\section{1- Isolation and identification of $\boldsymbol{E}$. coli:}

All samples were inoculated into tubes of freshly prepared nutrient broth and incubated aerobically at $37^{\circ} \mathrm{C}$ over night, followed by subculturing onto MacConkey's agar and eosin methylene blue agar plates for $24-48$ hours at $37^{\circ} \mathrm{C}$. Lactose positive colonies were confirmed as $E$. coli according to Gershwin (1990); Koneman et al. (1992) and Quinn et al. (1994).

Suspected colonies grown were picked on nutrient agar slopes and incubated at $37^{\circ} \mathrm{C}$ for 24 hours, then kept in refrigerator at $4{ }^{\circ} \mathrm{C}$ for further identifications according to (Edwards and Ewing, 1972). 


\section{2- Isolation of Salmonella:}

All samples were inoculated into tubes of Selenite-F and Tetrathionate broths and streaked out onto MacConkey and brilliant green agar after overnight incubation at $37^{\circ} \mathrm{C}$. Suspected colonies were subjected to biochemical testing according to (Adyin et al., 2001 and Echeita et al., 2002). Slide agglutination test was used for identification according to the Kauffmann-White Schema (Zahraei et al., 2007; Nori and Thong, 2012). Fnally identification of Salmonella typhimurium was done according to Waltner-Toews et al. (1986).

\section{3- Isolation of Campylobacter:}

Small portion of feacal samples was suspended in $0.85 \%$ saline, filtered through $0.45 \mathrm{~mm}$ Milipore filter papers. Filters were then cultured in Preston broth (Oxoid) and incubated overnight at $37^{\circ} \mathrm{C}$. Cultures were then inoculated onto Preston agar plates and incubated for $48 \mathrm{~h}$ in an atmosphere of 5\% oxygen, $10 \% \mathrm{CO} 2$ and $85 \%$ nitrogen. Suspected colonies were identified based on their motility, hydrolysis of sodium hippurate and sensitivity to cefalotin and nalidixic acid.

Each faecal sample was also cultured onto $5 \%$ sheep blood agar, incubated at $37^{\circ} \mathrm{C}$ for $24 \mathrm{~h}$ and inspected for the presence of other bacterial pathogens, e.g. Bacillus spp., Corynebacterium spp., Pseudomonas aeruginosa.

\section{4- Isolation of Clostridium perfringens:}

A loopful from a small piece of the feacal samples, was inoculated into tubes of freshly prepared Robertson's cooked meat medium at $37^{\circ} \mathrm{C}$ for 24 hours which had been boiled for 10 minutes and cooled rigidly prior to inoculation. Loopful from each tubes was streaked onto the surface of $10 \%$ sheep blood agar, then incubated anaerobically at $37^{\circ} \mathrm{C}$ for 24 hours. The plates were examined for characteristic colonies of Clostridium perfringens.

Subcultures from suspected colonies in cooked meat broth were made for further biochemical identification according to Koneman et al. (1992). Typing of $\boldsymbol{C}$.perfringens isolates was done by the intradermal inoculation test in guinea pigs according to Koneman et al. (1992).

\section{5- Serological identification of $E$. coli isolates:}

This was carried out according to Orskov and Orskov (1984). Slide agglutination test was done for demonstration of surface antigen, first using polyvalent antisera then for further identification by monospecific antisera, previously described (Ewing, 1986).

6- Susceptibility of E.coli isolates to various chemotherapeutic agents:

The isolates of E.coli were tested in vitro sensitivity to different antimicrobial agents by the disc diffusion method described by NCCLS (2004). The following antibiotic discs were used; chloramphenicol (30 mg), lincomycin (15mg), spectinomycin (200mg), amoxicillin $(25 \mathrm{mg})$, norfloxacin $(10 \mathrm{mg})$, neomycin $(30 \mathrm{mg})$, gentamycin $(30 \mathrm{mg})$ and doxycycline $(30$ $\mathrm{mg})$.

\section{7- Molecular technique: \\ Nucleic acid extraction}

Nucleic acids of all target agents were simultaneously extracted from specimens by use of a commercial nucleic acid isolation kit as described in the manufacturer's manual. In brief, $0.01 \mathrm{M}$ phosphate buffered saline ( $\mathrm{pH}$ 7.4) was added to each sample to make $30 \%$ fecal homogenates. After centrifugation for $1 \mathrm{~min}$ at $100 \times \mathrm{g}$ to pellet larger-size particles, 175 $\mu \mathrm{l}$ of the supernatant of each sample was carefully transferred into clean microcentrifuge tubes. Using a Fermentas kit (Gene JET Genomic DNA purification kit \#K0729. The extracted total nucleic acids in the elution plate were stored in $-80^{\circ} \mathrm{C}$ until used for PCR reaction.

Primers were chosen from published sequences with the aid of the Primer Select software (DNASTAR Inc, Madison, Wis.). Table 1 includes the bacteria, the primer sequences and the position of the primer. Primers were synthesized by Integrated DNA Technologies, Inc. (Coralville, Iowa).

\section{PCR technique}

PCR is a useful diagnostic tool because it is quick, specific, sensitive, and relatively inexpensive. A PCR which detects genes according to Stone et al. (1994) and China et al. (1996).

The identification and differentiation of specific gene via PCR amplification of virulence-associated genes commonly found in these E. coli strains. Primers specific for genes encoding the fimbrial subunits of K99, E coli $O 157$ and Salmonella typhimurium.

The 20- $\mu$ PCR mixture contain the specific primer, and $5 \mu \mathrm{l}$ bacterial DNA. Samples were amplified in a PCR thermal cycler (Perkin-Elmer) under the specific conditions.

\section{PCR design and amplification conditions for $\boldsymbol{E}$ coli O157 gene rfb}

$r f b$ O157, PCR assays for the detection of O157, H7 antigens s were screened by specific primers forward 5'- CGGACATCCATGTGATATGG -3' and the reverse 5'-TTGCCTATGTACAGCTAATCC-3' PCR condition and thermal cycles were similar to Paton and Paton (1998). The amplification conditions included 25 cycles of a denaturation step at $94{ }^{\circ} \mathrm{C}$ for $30 \mathrm{~s}$, primer annealing at $50{ }^{\circ} \mathrm{C}$ for $45 \mathrm{~s}$, and extension at $70{ }^{\circ} \mathrm{C}$ for $90 \mathrm{~s}$. The extension time was ramped for an additional $3 \mathrm{~s}$ per cycle and a final extension step of $10 \mathrm{~min}$ at $70{ }^{\circ} \mathrm{C}$ was performed. 
PCR design and amplification conditions for $K 99$ gene $\mathrm{F} 41$

$20 \mu \mathrm{l}$ of mix which contain the specific primer forward 5' TATTATCTTA GGTG GTATGG, 3' and the reverse primer $5^{\prime}$ GGTATCCTTTAGCAGCAGTATTTC, 3' according to Paton et al. (1993) and add a $5 \mu \mathrm{l}$ of samples and then using thermocycles Bekman with this condation The amplification conditions included 25 cycles of a denaturation step at $94{ }^{\circ} \mathrm{C}$ for $30 \mathrm{~s}$, primer annealing at $50{ }^{\circ} \mathrm{C}$ for $45 \mathrm{~s}$, and extension at $70{ }^{\circ} \mathrm{C}$ for $90 \mathrm{~s}$. The extension time was ramped for an additional $3 \mathrm{~s}$ per cycle and a final extension step of $10 \mathrm{~min}$ at $70{ }^{\circ} \mathrm{C}$ was performed.

PCR design and amplification conditions for $S$. Typhimurium flic gene

The oligonucleotide primers for PCR were synthesized according to Cohen et al. (1996a); Cohen et al. (1996b) and Jacb (2005). Considering reported nucleotide sequence of the flic gene (EMBL and Gen Bank accession number M18283 and sequence name
F2M47) of S. Typhimurium. The 20-mer forward primer (Flic),5'-TATTATCTTAGGTGGTATGG 3', reverse primer (Flic), 5'ACTCTTGCTGGCGGTGCGACTT -3 ', gene of $S$. typhimurium. The 559 bp fragment was specifically amplified using this set of primers. From pure cultures or genomic DNAs of Salmonella strains, amplification of flic gene was achieved on the thermal cycler as follows Initial denaturation at $94^{\circ} \mathrm{C}$ for 5 min., followed by 35 cycles of (denaturation at $94^{\circ} \mathrm{C}$ for $1 \mathrm{~min}$, annealing $55^{\circ} \mathrm{C}$ for $1 \mathrm{~min}$ and extension at $72^{\circ} \mathrm{C}$ for $1 \mathrm{~min}$ ). Final extension was carried out at $72^{\circ} \mathrm{C}$ for $10 \mathrm{~min}$ as reported by Sambrook et al. (1989).

DNA Products were electrophoresed in 2\% agarose gel (FMC Bioproducts, Rockland, Maine) for $1 \mathrm{~h}$ at $100 \mathrm{~V}$, stained with ethidium bromide, and photographed under UV light. Each experiment contained negative controls with all reagents except template DNA.

Table 1: Primer used in PCR for E coli O 157, E coli K 99 and S. Typhimurium.

\begin{tabular}{|c|c|c|c|}
\hline Virulence factor & Primer sequence $5^{\prime}-3^{\prime}$ & $\begin{array}{c}\text { Size of } \\
\text { product }(\mathbf{b p})\end{array}$ & Reference \\
\hline 0157( $r f b)$ & $\begin{array}{l}\text { CGGACATCCATGTGATATGG } \\
\text { TTGCCTATGTACAGCTAATCC }\end{array}$ & 259 & $\begin{array}{l}\text { (Paton and Paton, } \\
\text { 1998) }\end{array}$ \\
\hline K99 (F41) & $\begin{array}{l}\text { TATTATCTTAGGTGGTATGG } \\
\text { GGTATCCTTTAGCAGCAGTATTTC }\end{array}$ & 314 & (Paton et al., 1993) \\
\hline $\begin{array}{l}\text { S. Typhimurium. } \\
(\text { fliC })\end{array}$ & $\begin{array}{l}\text { CGGTGTTGCCCAGGTTGGTAAT } \\
\text { ACTCTTGCTGGCGGTGCGACTT }\end{array}$ & 559 & $\begin{array}{c}\text { (Cohen et al., 1996a } \\
\text { and Cohen et al., } \\
\text { 1996b) }\end{array}$ \\
\hline
\end{tabular}

\section{RESULTS}

Results in table 2, shows the bacterial isolates from examined rectal swabs of diarrheic calves. Out of 200 samples 159 samples $(79.5 \%)$ were positive for bacteriological isolates.

Recovered bacterial species from faeacal samples were E. coli, S. typhimurum, Campylobacter, Corynebacyerium, $P$. aeruginosa and $C$. perfringens with incidence of $47.5,9,7.5,6,4$ and $5.5 \%$, respectively.

The results in table 3 , illustrate Typing of $C$. perfringens isolates by intradermal inoculation test in Guinea pig and shoued that the incidence of toxigenic and non toxigenic strains were 81.9 and
$18.1 \%$ respectively. Type A predominant to type B with the incidence of 45.5 and $36.4 \%$ respectively.

The results in Table 4, show the serotyping of $95 E$. coli isolates, and revealed that the following serotypes:- K99 (21.1\%), O157 (17.9\%), O111 (9.5\%), O125 (11.6\%), O119 (15.8\%), O26(12.6\%), $\mathrm{O} 128(8.4 \%)$ and un typed E. coli $(3.2 \% \%)$.

In vitro sensitivity of the recovered isolates of E.coli to different antimicrobial agents was done. Table 5 shows that, E. coli isolates were highly sensitivite to enrofloxacin, flumequine and tetracycline. In contrast, these isolates were found to be resistant to ampicillin, erythromycin, gentamicin and penicillinG. 
From the Fig 1, good agreement in the test results was observed between the PCR panel and the traditional diagnostic methods, the results reached $97 \%$ to salmonella using PCR from the samples directly, 94 $\%$ to $E$ coli $k 99$ and $E$ coli $O 157$ the results reach to $95 \%$. We can record that the molecular characterize of $K 99$ (gene F41) the molecular bands appeared at 314 bp comparied with the molecular marker, but the $E$ coli $O 157$ for $r f b$ gene the molecular bands appeared at 259 bp. While the Flic gene of Salmonella typhimurium molecular bands appeared at $559 \mathrm{bp}$

Table 2: Incidence of bacteria in the examined faecal samples.

\begin{tabular}{cccccccc}
\hline Bacterial isolates & \multirow{2}{*}{ No. } & \multicolumn{2}{c}{ Single } & & Mixed & Total \\
\cline { 3 - 7 } & & No. & $\%$ & No. & $\%$ & No. & $\%$ \\
\hline E. coli & 200 & 86 & $43 \%$ & 9 & $4.5 \%$ & 95 & $47.5 \%$ \\
\hline S. typhimurium & 200 & 13 & $6.5 \%$ & 5 & $2.5 \%$ & 18 & $9 \%$ \\
\hline Campylobacter & 200 & 9 & $4.5 \%$ & 6 & $3 \%$ & 15 & $7.5 \%$ \\
\hline Corynebacterium & 200 & 8 & 4 & 4 & 2 & 12 & 6 \\
\hline P. aeruginosa & 200 & 6 & 3 & 2 & 1 & 8 & 4 \\
\hline C.perfringens & 200 & 7 & 3.5 & 4 & 2 & 11 & 5.5 \\
\hline Total & 200 & 129 & 64.5 & 30 & 15 & 159 & 79.5 \\
\hline
\end{tabular}

$\%$ Calculated according to the number of tested samples

No. : Number of tested samples

Table 3: Typing of $C$. perfringens isolated from faecal samples

\begin{tabular}{cccccc}
\hline Typing of C. perfringens & No. & $\%$ & $\begin{array}{c}\text { No. of non } \\
\text { toxigenic isolates }\end{array}$ & $\begin{array}{c}\text { Total number } \\
\text { of isolates }\end{array}$ \\
\hline C.perfringens Type (A) & 5 & 45.5 & & 2 & 18.1 \\
\hline C.perfringens Type (B) & 4 & 36.4 & & & 11 \\
\hline
\end{tabular}

$\%$ Calculated according to the total number of isolates

Table 4: Prevalence of $E$. coli serotypes in faecal samples from diarrheic calves.

\begin{tabular}{ccc}
\hline Serotypes & No. & \% \\
\hline K99 & 20 & 21.1 \\
\hline O157 & 17 & 17.9 \\
\hline O111 & 9 & 9.5 \\
\hline O125 & 11 & 11.6 \\
\hline O119 & 15 & 15.8 \\
\hline O26 & 12 & 12.6 \\
\hline O128 & 8 & 8.4 \\
\hline Un typed & 3 & 3.2 \\
\hline Total & 95 & 100 \\
\hline
\end{tabular}


Assiut Vet. Med. J. Vol. 58 No. 135 October 2012

Table 5: Susceptibility of E.coli isolates to different antimicrobial agents.

\begin{tabular}{|c|c|c|c|c|c|c|c|c|c|c|c|c|c|c|c|c|c|c|}
\hline \multirow{3}{*}{$\begin{array}{c}\text { Chemotherapeutic } \\
\text { agents. }\end{array}$} & \multicolumn{18}{|c|}{ Tested E.coli serotypes } \\
\hline & \multicolumn{3}{|c|}{ K99 } & \multicolumn{3}{|c|}{0157} & \multicolumn{3}{|c|}{0111} & \multicolumn{3}{|c|}{0125} & \multicolumn{3}{|c|}{0119} & \multicolumn{3}{|c|}{ O26 } \\
\hline & $\begin{array}{l}\text { NO. } \\
(20)^{*}\end{array}$ & $\%$ & $\overline{\mathrm{AA}}$ & $\begin{array}{l}\text { NO. } \\
(17)^{*}\end{array}$ & $\%$ & $\overline{\mathrm{AA}}$ & $\begin{array}{l}\text { NO. } \\
(9)^{*}\end{array}$ & $\%$ & $\overline{\mathrm{AA}}$ & $\begin{array}{l}\text { NO. } \\
(11)^{*}\end{array}$ & $\%$ & $\overline{\mathrm{AA}}$ & $\begin{array}{l}\text { NO. } \\
(15)^{*}\end{array}$ & $\%$ & $\overline{\mathrm{AA}}$ & $\begin{array}{l}\text { NO. } \\
(12)^{*}\end{array}$ & $\%$ & $\overline{\mathrm{AA}}$ \\
\hline \multicolumn{19}{|l|}{ Ampicillin } \\
\hline & 3 & 15 & $\mathrm{R}$ & 3 & 17.6 & $\mathrm{R}$ & 0 & 0 & $\mathrm{R}$ & 3 & 27 & $\mathrm{R}$ & 0 & 0 & $\mathrm{R}$ & 2 & 16.7 & $\mathrm{R}$ \\
\hline Chloramphenicol & 14 & 70 & IS & 12 & 70.6 & IS & 6 & 66.7 & IS & 9 & 81.8 & $\mathrm{~S}$ & 9 & 60 & IS & 8 & 66.7 & IS \\
\hline Enrofloxacin & 19 & 95 & $\bar{S}$ & 16 & 94.1 & $\bar{S}$ & 9 & 100 & $\bar{S}$ & 10 & 90.1 & $\bar{S}$ & 15 & 100 & $\mathrm{~S}$ & 12 & 100 & $\bar{S}$ \\
\hline Erythromycin & 4 & 20 & $\mathrm{R}$ & 2 & 11.8 & $\mathrm{R}$ & 1 & 1.1 & $\mathrm{R}$ & 0 & 0 & $\mathrm{R}$ & 2 & 22.2 & $\mathrm{R}$ & 1 & 8.3 & $\mathrm{R}$ \\
\hline Flumequine & 15 & 75 & $\bar{S}$ & 9 & 52.3 & IS & 4 & 44.4 & IS & 6 & 54.5 & IS & 13 & 86.7 & $\bar{S}$ & 10 & 83.3 & $\bar{S}$ \\
\hline Gentamicin & 3 & 15 & $\mathrm{R}$ & 2 & 11.8 & $\bar{R}$ & 1 & 11.1 & $\mathrm{R}$ & 1 & 9.1 & $\mathrm{R}$ & 2 & 13.3 & $\mathrm{R}$ & 1 & 8.3 & $\mathrm{R}$ \\
\hline Lincomycin & 13 & 65 & IS & 8 & 47.1 & IS & 3 & 33.3 & $\mathrm{R}$ & 3 & 27.3 & $\mathrm{R}$ & 8 & 53.3 & IS & 3 & 25 & $\mathrm{R}$ \\
\hline Penicillin-G & 0 & 0 & $\mathrm{R}$ & 0 & 0 & $\mathrm{R}$ & 1 & 11.1 & $\mathrm{R}$ & 2 & 18.1 & $\mathrm{R}$ & 0 & 0 & $\mathrm{R}$ & 1 & 8.3 & $\mathrm{R}$ \\
\hline Spectinomycin & 14 & 70 & IS & 10 & 58.8 & IS & 6 & 66.7 & IS & 7 & 63.6 & IS & 9 & 60 & IS & 7 & 58.3 & IS \\
\hline Streptomycin & 13 & 65 & IS & 7 & 41.2 & $\overline{\mathrm{R}}$ & 5 & 55.6 & IS & 7 & 63.6 & IS & 8 & 53.3 & IS & 3 & 25 & $\overline{\mathrm{R}}$ \\
\hline Tetracycline & 16 & 80 & $S$ & 11 & 64.7 & IS & 7 & 77.7 & $S$ & 7 & 63.6 & IS & 10 & 66.7 & $S$ & 7 & 58.3 & IS \\
\hline
\end{tabular}

No. Number of sensitive isolates.

*. Number of isolates.

$\%$ : Percentage of sensitive isolates in relation to total isolates.

AA: Antibiogram activity. S: sensitive.

IS: intermediate sensitive. R: resistant.

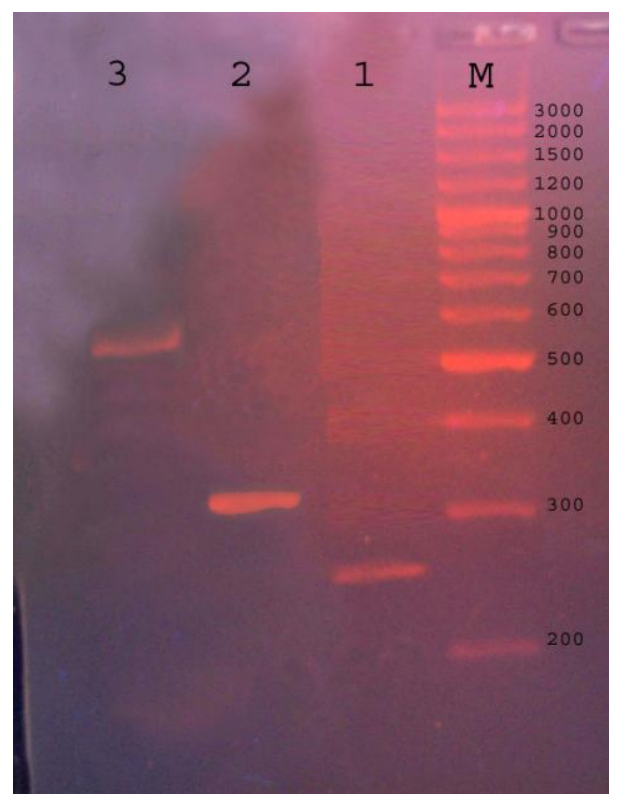

Fig. 1: Ethidium bromide stained 2\% agarose gel electrophoresis showed the amplified fragment

M marker 100 bp standard (\# SM 0323 ) Fermantas.

Lane 1 : E coli $O 157$ gene $r f b$

Lane 2 : E coli $K 99$ gene $F 41$

Lane 3 : S. Typhimurium gene flic 


\section{DISCUSSION}

Neonatal calf diarrhea is considered one of the most serious constraints of animal production. The incidence of calf diarrhea occurs all over the year with some increase in calving seasons.

The results in Table 2, show that, the total bacteria isolated from faeacal samples were $E$. coli, S.typhimurium, Campylobacter, Corynebacyerium, $P$. aeruginosa and $C$. perfringens with incidence of $47.5,9,7.5,6,4$ and $5.5 \%$, respectively. Our findings are similar to previous data that found the E. coli was the most common bacteria isolated from fecal samples of diarrheic calves, (China et al., 1998 and Harbby, 2002). Also the results agreed with that obtained by El-Hamamy et al. (1999), who recorded that cultures of swabs from diarrheic calves revealed that, the predominant isolate was E-coli $(52.5 \%)$, enterobacter aerogense (15\%), proteus vulgoris (12.5\%) and Salmonella spp. (5\%). Also other results (Ibrahim, 2007) revealed that 7 of 150 samples were positive for $E$-coli with an incidence of $24.66 \%, E$. coli $K 99$ were isolated from 13 samples, (Quigley et al., 1995) recorded that out of 150 samples $22.7 \%$ were positive for Campylobacter, Salmonella which were isolated in 22 samples with an incidence of $14.66 \%$. The same results are obtained by Novert and Nawal (2002), who detected $E$-coli K99 antigen in 13 fecal samples $(23.2 \%)$ out from 56 fecal samples obtained from untreated diarrheic calves aged from one day up to 3 weeks of age, using the traditional culture method. Also same results of supported (Bendali et al., 1999a), who concluded that E-coli was isolated from $20.3 \%$ diarrheic fecal samples out of 3080 fecal samples obtained from neonatal calves with diarrhea, it appeared during first days of life.

Different clostridia species cause intestinal disorders and enterotoxaemia in various animals species including neonatal calves demonstrated that, in neonatal calves enterotoxaemia is defined as a sudden death syndrome with lesions of hemorrhagic enteritis (Manteca et al., 2000), the infectious etiology has not been identified, although C.perfringens is often regarded as responsible (Popoff, 1990).

The results in table 3 , show the Typing of $C$. perfringens by intradermal injection of Guinea pig revealed that the incidence of toxigenic and non toxigenic strains were 81.9 and $18.1 \%$ respectively. Typing toxigenic strains of $C$. perfringens revealed that the type A was the most predominant than type B with the incidence of $45.5 \%$ and $36.4 \%$ respectively, these results agrees with that obtained by Haschek et al. (2006), who found that prevalence of $C$ .perfringens was $9.1 \%$ in collected feces of 230 calves with and without diarrhea during the winter period 2004/2005 in 100 Austrian farms (Styria and
Lower Austria), a higher prevalence of infection was reported by Haschek et al. (2006), who examined fecal samples taken from 344 calves aging between one day to 4 months old from dairy farms in Fayoum, Kafr El-sheikh and Beharia Governorates, 293 of them were apparently healthy and 51 of them were diarrheic. Microbiological examination revealed that, the isolation of $C$. perferingens was $71.32 \%, 59.65 \%$ and $57.01 \%$ from the apparently healthy calves and $96.15 \%, 88.89 \%$ and $87.5 \%$ from the diseased diarrhoeic calves in Fayoum, Kafr El-sheikh and Beharia Governorates respectively. The highest percentage of isolations was in 1 day-1-week-old calves as it reached $80.61 \%$. (Harbby, 2002), examined fecal swabs collected from 200 calves showed that 150 diarrhoeic, 20 apparently healthy and 30 intestinal samples, aged from one day to 12 weeks old. C.perfringens were detected in $66.7 \%$.

The results in Table 4 shows that serological serotyping of $95 \mathrm{E}$. coli isolates, revealed that the $E$. coli were typed as $K 99(21.1 \%), \mathrm{O} 157(17.9 \%), 0111$ (9.5\%), O125 (11.6\%), O119 (15.8\%), O26(12.6\%), $\mathrm{O} 128(8.4 \%)$ and untyped E. coli $(3.2 \% \%)$. These findings are similar to previous data stated that the most common $E$. coli serotypes isolated from diarrheic fecal samples was O119, O111, O126, and O78 (Tamaki et al., 2005). Similarly, (Badouei et al., 2012). Isolated O157:H7, O111, and O26 serotypes from 297 fecal samples from 200 diarrheic and 97 non-diarrheic calves. The most common serogroup was $\mathrm{O} 26(18.4 \%)$. The same results were obtained by John et al. (2007) who isolated EHEC O26 and EHEC O111 from diarrheic and non-diarrheic young calves from 115 different farms. Of the 257 calves with diarrhea, $37(14.4 \%)$ and $32(12.5 \%)$ was found positive EHEC O26 and EHEC O111,respectively. Suggesting that EHEC O26 and O111 are possible causes of the disease in infected neonatal calves. The high percentage of bacterial isolation in winter months may be attributed to increased relative humidity which activate microorganisms and increase number of births which facilitated contamination and spread of infection.

Results in table 5 shows that, the in vitro sensitivity of the recovered isolates of E.coli to different antimicrobial agents were highly sensitivite to enrofloxacin, flumequine and tetracycline. In contrast, these isolates were found to be resistant to ampicillin, erythromycin, gentamicin , lincomycin and penicillin-G. The present results agreed with those of Sadiek and Sohair (1999), who studied antibiotic sensitivity of fecal samples from diarrheic calves and found that enrofloxacin was the antibiotic of choice for most bacterial isolates (E. coli, Salmonella species, Klebsiella species, and Proteus species). In another study, in vitro sensitivity testing of isolated bacteria from the feces of diarrheic calves showed 
that ciprofloxacin, enrofloxacin, and gentamicin were the most effective drugs (El-Gaml et al., 2001). Recent work has also shown that ceftiofur and enrofloxacin were highly efficient antibiotics in treatment of neonatal calf diarrhea, as indicated by antimicrobial sensitivity tests (Aba-Alkhalil and ElNaenaeey, 2003). In addition, most E. coli isolates from diarrheic calves had been shown to be resistant to kanamycin, gentamycin, chloramphenicol, tetracycline, and ampicillin (Sato et al., 2005).

Showed that the molecular characterized of $K 99$ (gene F41) the molecular bands appeared at $314 \mathrm{bp}$ comparied with the molecular marker (Fig, 1), on the other hand $E$ coli $O 157$ the $r f b$ gene the appeared at 259 bp. While the Flic gene of salmonella Typhimurium molecular bands appeared at 559 bp. $S$. typhimurium flic gene has been cloned and sequenced (Nicols et al., and Swenson et al., 1994). Specific primers were designed by Cohen et al. (1996a) and Cohen et al. (1996b) which had the ability to amplify region of the flic gene from Salmonella strains but not from E. coli. These results agreed with the results of Jones et al. (1988); Segall and Lindberg (1993) and Seleim et al. (2004). All Salmonella strains either standard or isolated from fecal samples were positive with PCR and the 559 bp PCR product was observed on agarose gel electrophoresis. This results confirms the result of Cohen et al. (1996a) and Cohen et al. (1996b). All bacteriologically positive fecal samples were positive with PCR and the specific PCR product (559 bp fragment).

Our results indicate that the PCR amplification of the flic gene sequence of $S$. typhimurium could be used as a target sequence for rapid and sensitive method for direct detection of Salmonella serovars in the fecal samples of diarrheic and contact apparently normal calves.

Diarrhoea due to the Escherichia coli O 157 gene rfb and $K 99$ gene $F 41$ is one of the most frequent bacterial diseases in neonatal calves and the predominant pathogen cultured from calves with septicaemia (Lofstedt et al., 1999). E coli was the bacterial agent cultured with the highest frequency from diarrhoeic and healthy calves in our study, a finding that agrees with results of Bendali et al. (1999a) and Garcia et al. (2000).

E. coli belonging to the $\mathrm{O} 157$ serogroup have been mainly isolated from cattle which are considered a natural reservoir of these bacteria (Armstrong et al., and Dombek et al., 2000). As demonstrated in the present study, none of the O157-positive isolate the $r f b$ gene as tested by PCR. E. coli O157:H7- strains have been isolated from cattle and have emerged as important etiological factor of hemorrhagic colitis. As demonstrated in the present study, that are characteristic for E. coli isolates pathogenic for humans. Therefore, these bacteria can be considered potentially virulent microorganisms for man. The genetic analysis of selected O157:H7- isolates, performed with random amplification of DNA sequences, revealed that bacteria possessing the same but also different virulence-associated factors represented related clonal lineages. the obtained result agreed with that of Snodgrass et al. (1986), as the isolated E.coli with an incidence of $(50.76 \%)$. lethal E.coli was found in 6/32 samples (West et al., 2007).

Therefore, the PCR panel could help diagnosticians rapidly determine the causative agents for bovine diarrhea in the early stages of disease and help practitioners which initiate appropriate treatments or interventions quickly. Study was supported in part by funding from Iowa calf scour Fund. It was found that the PCR is relatively rapid and highly sensitive (Singer et al., 2006).

\section{CONCLUSION}

The aim of the present study was to determine the association between E. coli and Salmonella (one of the most important enteropathogenic bacteria causing calf diarrhea). Serotyping of E.coli were identified in percentage infection of Salmonella and E.coli was detected in the newly developed PCR described in the current study is specific and more sensitive than other traditional diagnostic methods and drastically decreases turnaround time, labor, and cost. Therefore, the PCR panel could help diagnosticians to determine rapidly the causative agents for bovine diarrhea in the early stages of disease and help practitioners initiate appropriate treatments or interventions quickly.

Study was supported in part by funding from Iowa calf scour fund. It was found that the PCR is relatively rapid and highly sensitive (Singer et al., 2006).

The PCR method was also highly sensitive, as it correctly detected all genes of interest in $100 \%$ of the strains and isolates containing them. This assay could be useful in diagnostic situations for identification and characterization of $E$. coli isolated from calves with diarrhea. These results highlight the usefulness of the multiplex PCR for the rapid detection of the two serotypes of Salmonella from field samples especially after pre-enrichment on RV media. Moreover, detecting S. typhimurium and S. enteritidis by this assay was carried out within two days opposed to five to six days by the bacteriological and serological methods (Moussa et al., 2012). 


\section{REFERENCES}

Farid, A.; Eid, G.E.; Abdel-Mawla, Y.R. and Nagat, A.S. (2001): Evaluation of the efficacy of Escherichia coli (K99) vaccine on the incidence of Escherichia coli and immunity in buffaloes. Vet. Med. J., Giza, 49(3): 385-399.

Ibrahim, E.D. (2007): Studies on microbial causes of diarrhea in calves. M.V.Sc. Thesis, Fac. Vet. Med., Kafr El-Sheikh Univ.

Novert, A. and Hammad, A. (2001): Studies on mycotic and bacterial enteritis. J. Egypt. Vet. Med. Assoc, 61(6 B): 190-201.Oxoid (1987): Agents and main istributors, the manual, $6^{\text {th }}$ Ed.

Ashraf, N.M.R. (2007): Enzootic gram negative bacteria associated with diarrhea in neonates in Egypt. Ph.D Thesis, Dept. of Microbiol., Fac. Vet. Med., Alex. Univ.

Snodgrass, DR.; Terzolo, HR. and Sherwood, D. et al., (1986): Aetiology of diarrhoea in young calves. Vet Rec 119: 31-34.

Roberts, J.A. (1993): Toxocara vitulorum in Ruminants. Veterinary Bulletin, v.63, n.6, p.545-67,

El-Ghari, M.M.; El-Rashidy, A.A.; Mettias, K.N.; Hassen, E.R. and Hassen, H.M. (1994): Studies on neonatal diarrhea in buffalo calves. In: WORLD BUFFALO CONGRESS, 4., São Paulo,. Proceedings. p.361-3.

Prescott, Bueschel D.M.; Keel, MK.; Glock, RD.; Cuneo, P.; DeYoung, DW.; Reggiardo, C.; Trinh, HT. and Songer, JG. (2008): A possible role for Clostridium difficile in the etiology of calf enteritis. Vet. Microbiol. Mar. 18: 127(34): 343-352.

Achá, SJ.; Kühn, I.; Jonsson, P.; Mbazima, G.; Katouli, M. and Möllby, R. (2004): Studies on Calf Diarrhoea in Mozambique: Prevalence of Bacterial Pathogens Acta Vet. Scand. 45(1): 27-36.

Schoenians, (2006): Diarrhoea in small ruminants In: small Ruminant fact sheet series. University of Maryland cooperative Extention. Pp1-4.

Myers, L.L.; Firehammer, B.D.; Border, M.M. and Shop, D.S. (1984): Prevalence of enteric pathogens in the feces of healthy beef calves. Am. J. Vet. Res., 45: 1544-1548.

De Rycke, J.; Bernard, S.; Laporte, J.; Naciri, M.; Popoff, M.R. and Rodolakis, M.R. (1986): Prevalence of various enteropathogens in the feces of diarrheic and healthy calves. Ann. Rech. Vét. 1, 17: 159-168.

Uhde, Fl.; Kaufmann, T.; Sager, H.; Aldini, SZ.; Anoni, R.; Schelling, E. and Meylan, M. (2008): Prevalence of four enteropathogens in the faeces of young diarrhoeic dairy calves in Switzerland. Vet. Rec. Sep. 163 (12): 362:6
Gyles, C.L. (1993): Escherichia coli. In: Gyles CL،Thoen CO, eds. Pathogenesis of Bacterial Infections in Animals, 2nd ed, Ames, Iowa: Iowa State Univ Pr, 164-187

Radostits, O.M.; Gay, C.C.; Hinchcliff, K.W. and Constable, P.D. (2007): Veterinary Medicine, 10th edition. PP. 847-888. Saunders, Philadelphia.

Campos, L.C.; Franzolin, M.R. and Trabulsi, L.R. (2004): Diarrheogenic Escherichia coli categories among the traditional enteropathogenic Escherichia coli O serogroups- a review Mem. Inst. Oswaldo Cruz.; 99(6): 545-552.

Dean-Nystrom, E.A.; Bosworth, B.T.; Cray Jr, W.C. and Moon, H.W. (1997): Pathogenicity of Escherichia coli O157:H7 in the intestines of neonatal calves Infection and immunity Infect. Immun. May Vol. 65 No. 5 1842-1848

Tamaki, Y.; Narimatsu, H.; Miyazato, T.; Nakasone, N.; Toma, C. and Iwanaga, M. (2005): The relationship between $\mathrm{O}$ antigens and pathogenic genes of diarrhea- associated E. coli. Jpn. J. Infect. Dis., 58: 65-69.

Badouei, M.A.; Salehi, T.Z.; Khorasgani, M.R.; Tadjbakhsh, H.; Brujeni, G.N. and Nadalian, M.G. (2010): Virulence gene profiles and intimin subtypes of Shiga toxin-producing Escherichia coli isolated from healthy and diarrhoeic calves. Vet. Rec. 167(22): 858-61.

Aarestrup, FM.; Rene, S.; Hendriksen, J.L.; Katie, G.; Kathryn, T.; Patrick, F.; McDermott, F.J. and Peter, GS. (2007): International spread of multidrug-resistant Salmonella Schwarzengrund in food products. Emerging Infectious Diseases, 13 (5): 726-731.

Alizadeh, AH.; Behrouz, N.; Salmanzadeh, S.; Ranjbar, M.; Azimian, MH.; Habibi, E.; Jaafari, F.; Zolfagharian, K. and Zali, MR. (2007): Escherichia coli, Shigella and Salmonella species in acute diarrhoea in Hamedan, Islamic Republic of Iran. East. Mediter. Hlth. J. 13. (2): 243-249.

Kottwitz, L.B.M.; Back, A.; Leão, JA.; Alcocer, I.; Karan, M. and Oliveira, TM. (2008): Contaminação por Salmonella spp. emuma cadeia de produção de ovos de uma integração de postura commercial. Arquivos Brasileiro de Med. Vet. Zootecnia, 60 (2): 496-498.

Antoine, ST.; Annaelle, K. and Anne, B. (2008): Epidemiological analysis of Salmonella enterica from beef sampled in the slaughter house and retailers in Dakar (Senegal) using pulsed-field gel electrophoresis and antibiotic susceptibility testing.J. Food Microbiol. 123: 191-197.

Zahraei, T.; Tadjbakhsh, H.; Atashparvar, N.; Nadalian, MG. and Mahzounieh, M.R. (2007): Detection and identification of Salmonella 
Typhimurium in bovine diarrhoeic fecal samples by immunomagnetic separation and multiplex PCR assay Zoonosis Public Health, 54: 231-236.

Herikstad, H.; Motarjemi, Y. and Tauxe, RV. (2002): Salmonella surveillance: a global survey of public health serotyping. Epidemiol. Infect. 129: $1-8$.

Malorny, B.; Hoorfar, J.; Hugas, M. and Heuvelink, Helmuth R. (2003): Interlaboratory diagnostic accuracy of a Salmonella specific PCR-based method.Int. J. Food Microbiol. 89: 241-249.

Stone, G.G.; Oberst, R.D.; Hays, M.P.; McVey, S. and Chengappa, M.M. (1994): Detection of Salmonella serovars from clinical samples by enrichment broth cultivation-PCR procedure.J. Clin. Microbiol. 32, (7): 1742 - 1749.

China, B.; Pirson, V. and Mainil, J. (1996): Typing of bovine attaching and effacing Escherichia coli by multiplex in vitro amplification of virulence-associated genes. Appl. Environ. Microbiol. 62: 3462-3465.

Gershwin, L.J. (1990): The physiochemical and biological basis of immunity. In: Biberstein, E.L., Zee, Y.C. (Eds.): Review of Veterinary Microbiology. Blackwell Scientific Publications, Boston, USA. 29-30.

Koneman, E.W.; Allen, S.D.; Dowell, V.R.; Janda, W.H. and Sommers, H.M. (1992): Color atlas and Textbook of Diagnostic Microbiology. $4^{\text {th }}$ Ed., J.B.Lippincott CO., New York.

Quinn, P.J.; Carter, M.E.; Markey, B.K. and Carter, G.R. (1994): Clinical Veterinary Microbiology.Mosby. Yearbook Europe Limited.

Edwards, P.R. and Ewing, W.H. (1972): Identification of Enterobactericeae. Burgess publ Co.Minnece polis, Minnesota, p.103-104.

Adyin, F.; Mmur, S.; Gokce, G.I.; Genc, O. and Guler, M.A. (2001): The isolation and identification of bacteria and parasites from diarrhea calves in Kars District. Kafkas universitesi veteriner Fakultesi, Dergisi. 7, (1): 7.

Echeita, MA.; Herrera, S.; Garaizar, J. and Usera, MA. (2002): Multiplex PCR based detection an identification of the most common Salmonella second-phase flagellar antigen. Res. Microbiol. 153: $107-113$

Nori, EM. And Thong, KL. (2010): Differentiation of Salmonella enterica based on PCR detection of selected somatic and flagellar antigen. Afr. J. Microbiol. Res. 4(9): 871-879.

Waltner-Toews, D.; Martin, S.W. and Meek, A.H. (1986): An epidemiological study of selected calf pathogens on Holstein dairy farms in southwestern Ontario. Canadian Journal of Veterinary Research, 50: 307-313.
Orskov, I. and Orskov,F. (1984): Serotyping of Escherichia coli. Methods Microbiol. 14: 43112.

Ewing, W.H. (1986): Edwards and Ewing's identification of Enterobacteriaceae, $4^{\text {th }}$ edition, pp,135-172. New York: Elsevier.

NCCLS-National Committee for Clinical Laboratory Standards, (2004): Performance standards for Antimicrobial susceptibility testing. Fourteenth informational supplemented. M100-S14, Wayne, PA, USA.

Paton, AW. and Paton, JC. (1998): Detection and Characterization of Shigatoxigenic Escherichia coli by Using Multiplex PCR Assays for stx 1 , stx2, eaeA, Enterohemorrhagic E. coli hlyA, $r f b \mathrm{O} 111$, and $r f b \mathrm{O} 157$. J. Clin. Microbiol., 36: 598-602.

Paton, A.W.; Paton, J.C. and Manning, P.A. (1993): Polymerase chain reaction amplification, cloning and sequencing of variant Escherichia coli Shiga-like toxin type II operons. Microb. Pathog. 15: 77-82.

Cohen, H.J.; Subbaiah, M.; Meehanda, S.M. and Lin, W. (1996 a): PCR Amplification of the FimA Gene Sequence of S. typhimurium, a specific method for detection of Salmonella spp. Appl. Environ. Microbiol. 62: 4303-4308.

Cohen, N.D.; Martin, L.J.; Simpson, R.P.; Wallis, D.E. and Neibergs, H.L. (1996 b): Comparison of polymerase chain reaction and microbiological culture for detection of Salmonellae in equine feces and environmental samples. Am. J. Vet. Res. 57: 870-876.

Jacb Sonne-Hansen and Saloomeh M. Jenablan, (2005): Molecular serotyping of Salmonella: identification of the phase $1 \mathrm{H}$ antigen based on partial sequencing of the $f l i C$ gene. Volume 113, Issue 5, pages 340-348,

Sambrook, J.; Fritsch, F.F. and Maniatis, T. (1989): Molecular Cloning: a Laboratory Manual. 2nd edition. Cold Spring Harbor. NY: Cold Spring Harbor Laboratory Press.

China, B.; Pirson, V. and Mainil, J. (1998): Prevalence and molecular of attaching effacing E.coli among calf populations in Belgium. 63(2-4): 249-259.

Harbby, H.A. (2002): Bacterial causes of diarrhea in small animals (Kids, lambs and calves) in Sultanate of Oman. J. Egypt. Vet. Med. Ass., 62 (3): 227.

El-Hamamy, M.M.; El-Boushi, M.E. and Fataih, H.A. (1999): Some studies on newly born calves' problems with relationship to their immune status. SCVM J, II (2): 289.

Quigley, J.D.; Martin, K.R.; Bemis; D.A; and Potgieter, L.N.D. (1995): Effects of housing and colostrum feeding on serum immunglobulins, growth, and fecal scores of Jersey calves. J. Dairy Sci. 78: 893. 
Novert, M.H. and Nawal M.A. Youssef (2002): Rapid detection of E. coli $K 99$ antigen, Rota virus and corona virus in feces of diarrheic calves $\mathrm{J}$. Egypt Vet. Med. Ass. 62(4): 219-227.

Bendali, F.; Bichet, H.; Schelcher, F. and Sanaa, M. (1999a): Pattern of diarrhea in newborn beef calves in South-West France. Vet. Res., 30 (1): 61 .

Manteca, C.; Doube, G. and Jauniaux, T.G. (2000): L énterotoxémie en elogique. II. Epizootological él émentaire et pathologie descriptive. Ann Med. Vet., 144: 75-84.

Popoff, M.R. (1990): Les enterotoxemies. Rev. Med. Vet., 479- 491.

Haschek, B.; Klein, D.; Benetka, V.; Herrera, C.; Sommerfeld, I.; Vilcek, S.; Moestl, K. and Baumgartner, W. (2006): Detection of Bovine Torovirus in Neonatal Calf Diarrhea in Lower Austria and Styria (Austria). J. Vet. Med. Series B; 53 (4): 160-165

Ramzy, H.H. and Abd El-Sayed, (2001): Bacteriological and serological studies on the different species of genus clostridium associated with neonatal calf diarrhea. M.Sc. (Microbiology). Faculty of Veterinary Medicine. Cairo University

John Hwa Lee; Jin Hur and Barry D. Stein, (2007): Occurrence and characteristics of enterohemorrhagic E. coli $\mathrm{O} 26$ and $\mathrm{O} 111$ in calves associated with diarrhea.Vet. J.

Sadiek, A. and Sohair, Z.H. (1999): Acute enteritis in neonatal calves in Sohag governorate with special reference to aetiology, clinico-chemical aspects and therapy. Assuit Vet. Med. J., 42(83): 200-212.

El-Gaml, A.M.; Hashem, M.EL. and Hatab, M. (2001): Diarrhea in kids attributed to enterobacteria and cryptosporidium. Assiut Vet. Med. J., 45(89): 132-141.

Aba-Alkhalil, and El-Naenaeey, E.Y. (2003): Evaluation of antimicrobial action of ceftifour sodium (Excenel), in vitro and vivo. Suez canal Vet. Med. J., VI (2): 42-51.

Sato, K.; Baretlett, P.C. and Saeed, M.A. (2005): Antimicrobial susceptibility of $E$. coli isolates from dairy farms using organic versus conventional production methods. J. Am. Med. Assoc., 226 (4): 589-594.

Nicols, WA.; Clegg, S. and Brown, MR. (1990): Characterization of type I fimbrial subunit gene (FimA) of Serratia marcescens. Mol. Microbiol.4: 2119-2126.
Swenson, DL.; Clegg, S. Old, DC. (1994): Frequency of the fimA genes among Salmonella serovars. Microbiol. Pathol. 10: 487-490.

Jones, P.W.; Collins, P. and Aitken, M.M. (1988): Passive protection of calves against experimental infection with S. typhimurium. Vet. Rec. 123: 536-

Segall, T. and Lindberg, A.A. (1993): Oral vaccination of calves with an aromatic $S$. dublin (09, 12) hybrid expressing 04, 12 protects against Salmonella Dubillin (09, 12) bill not against $S$. typhimurium $(04,5,12)$. Infect. Immun. 61: 1222-1231.

Seleim, R.S.; Sahar, R.; Novert, M.H. and Gohran, R.A. (2004): Salmonella infection in calves: virulence proteins and its immunogenic properties. J. Vet. online.

Lofstedt, J.; Dohoo, I.R. and Duizer, G. (1999): Model to predict septicaemia in diarrheic calves. Journal of Veterinary Internal Medicine, 13: 81-88.

Garcia, A.; Ruiz-Santa-Quiteria, J.A.; Orden, J.A.; Cid, D.; Sanz, R.; Gomez-Bautista, M. and de la Fuente, R. (2000): Rotavirus and concurrent infections with other enteropathogens in neonatal diarrheic dairy calves in Spain. Microbiology and Infectious Disease, 23: 175183.

Armstrong, G.L.; Hollingsworth, J. and Morris, J.G. (1996): Emerging foodborne pathogens: Escherichia coli O157:H7 as a model of entry of a new pathogen into the food supply of the developed world. Epidemiol. Rev., 18: 29-51.

Dombek, P.E.; Johnson, L.K.; Zimmerley, S.T. and Sadowsky, M.J. (2000): Use of repetitive DNA sequences and the PCR to differentiate Escherichia coli isolates from human and animal sources. Appl. Environ. Microbiol., 66: 2572-2577.

West, D.M.; Sprigings, K.A. and Cassar, C. (2007): Rapid detection of $E$. coli virulence factor genes using multiplex real-time TaqMan PCR assays. Vet. Microbiol, 122: 323-331

Singer, R.S.; Cooke, C.L.; Maddox, C.W.; Isaacson, R.E. and Wallace, R.L. (2006): Use of pooled samples for the detection of Salmonella in feces by polymerase chain reaction. J. Vet. Diagn. Invest. 18: 319-325.

Moussa, I.M.1.; Ashgan, M.H.; Mahmoud, M.H. and Al-Doss, A.A. (2012): Rapid detection and characterization of Salmonella enterica serovars by multiplex polymerase chain reaction assay African Journal of Biotechnology Vol. 11(14), pp. 3452-3458, 
Assiut Vet. Med. J. Vol. 58 No. 135 October 2012

\section{المسببات البكتريولوجية للأسهال في العجول حديثي الولادة في محافظة المنوفية \\ الهام إبراهير عطوة ، ايمان محمود فريد شرف ، ايمان مجدى زخاري}

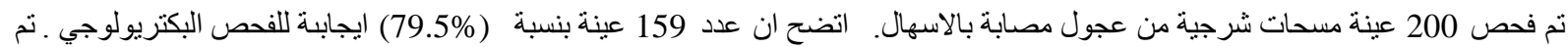

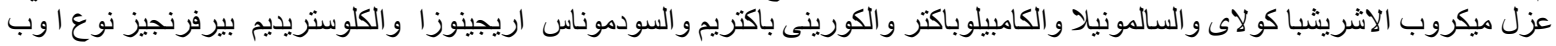

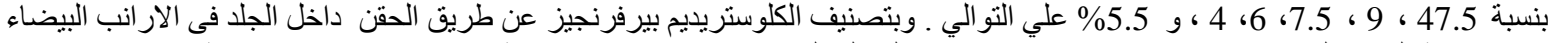

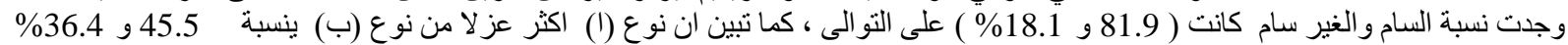

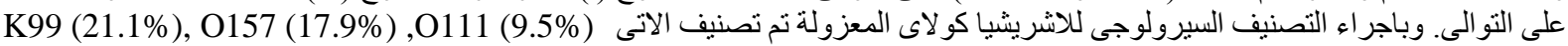
و وغير مصنفة بنسبة 3.2 \%. O125 (11.6\%), O119 (15.8\%), O26(12.6\%), O128 (8.4\%)

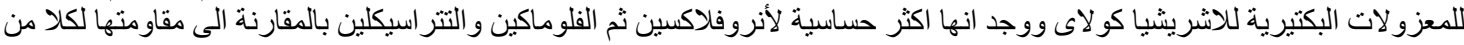

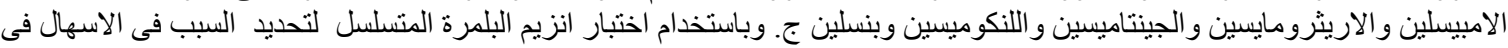

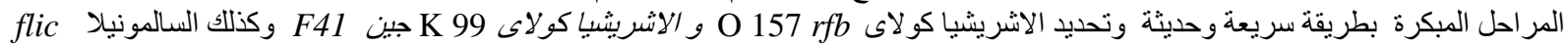
وجد انة الجين يظهر عند 259 و 314 و 559 على التوالى. 